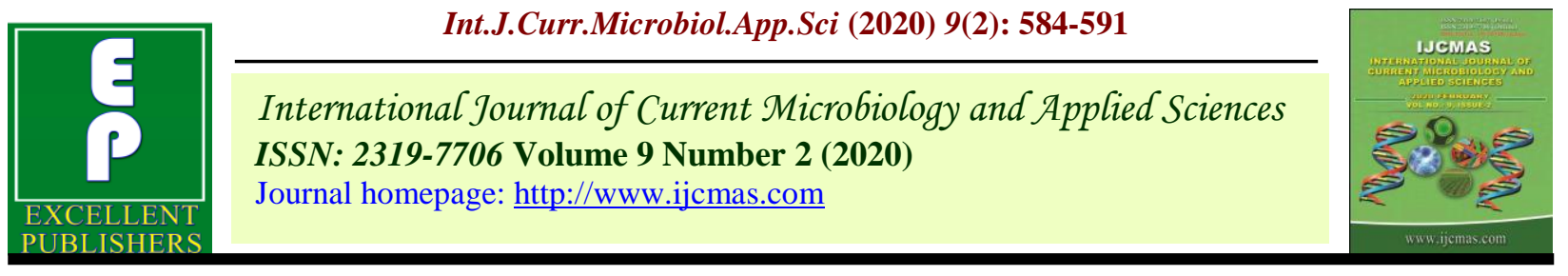

Original Research Article

https://doi.org/10.20546/ijcmas.2020.902.073

\title{
Screening of Bacteria Present in Cow Dung
}

\author{
Ayush Tomar, Shalu Choudhary*, Lalit Kumar, Megha Singh, \\ Nisha Dhillon and Sonam Arya
}

College of Applied Education and Health Sciences, Meerut, India

*Corresponding author

\section{A B S T R A C T}

\section{Keywords}

Bacteria, Cow dung, Lactobacillus plantarum

\section{Article Info}

Accepted:

08 January 2020

Available Online:

10 February 2020
Cow dung has a wide range of micro-organisms, like- endospore forming Bacillus, Enterococcus \& protozoa. In the present investigation attempts were made to isolate bacteria using nutrient agar media (NAM). The isolated bacteria were identified on the basis of their colony characteristics, morphology, Gram's staining and biochemical test. It was observed that spore forming bacillus were the predominant type of organism, which possibly helped in maturation of manure forming.

\section{Introduction}

Cow dung is excreted by bovine animal species, which are herbivores. It consists of undigested residues of consumed matter which has passed through the cow's gastrointestinal system (Teo \& Teoh, 2011). Cow dung is widely used in formation of manure which is used as bio-fertilizers. Manure of cow dung enhances the minerals of soil and also develops resistance power of plants against pests and plant diseases. It contains about $80 \%$ of water and has some part of undigested plants material that have high amount of organic substance.

The microflora of cow dung contains a wide number of bacteria such as - Bacillus, like lactobacillus as central endospore forming bacillus some cocci, fungi and yeast such as Saccharomyces (Sharma \& Singh, 2015). According to Ware et al., (1988), lower part of the gut of cow has probiotic acitivity due to presence of different types of microorganisms like Lactobacillus plantarum, Lactobacillus casei, Lactobacillus acidophilus, Bacillus subtilis, Entrococcus diactylactis, Bifido bacteirum and yeasts (Saccharomyces cerevisiae). There are several evidences to show that fresh cow dung and cow urine are antifungal and antiseptic in nature, which might be due to secretion of antimicrobial metabolites by cow dung micro-flora (Sharma \& Singh, 2015). 
The aim and objective of this study was to isolate bacteria from cow dung, using nutrient agar media (NAM). The isolated bacteria were identified on the basis of their colony characteristics, morphology, Gram's staining and biochemical test, so that we can identify which microorganism will possibly helped in maturation of manure formation.

\section{Materials and Methods}

In this study, cow dung was collected and left it for some days for the isolation of different types of bacteria. Using nutrient agar media (NAM), the bacteria from cow dung were characterized and identified on the basis of Gram's staining method and biochemical analysis.

For fulfilling the requirement of objective, we required following materials and chemicals:

Cow dung, Petri plates, test tubes, Nutrient agar media, Inoculating loop, sprit lamp, LAF, autoclave, Hot air oven, Sample container, Cotton, Foil paper, Slides, Distilled water, Cotton swab, Phosphate buffer saline solution (PBS solution), pH strip, Incubator, Microscope, Gram's staining kit and Normal saline solution.

\section{Method}

Cow dung was Collected and placed at a place from where samples were collected from upper surface and lower surface in sterile containers at a specific intervals- $2^{\text {nd }}$ day, $7^{\text {th }}$ day, $15^{\text {th }}$ day, $21^{\text {st }}$ day and $31^{\text {st }}$ day. In this process streak plate method and pour plate method were used.

\section{Isolation of bacteria}

Nutrient agar media was used for the isolation of bacteria from cow dung.

\section{Sample-1 ${ }^{\text {st }}$ (After 2 days)}

Cow dung sample was streaked on nutrient agar media with the help of sterilized inoculating loop. Upper surface sample and lower surface sample were streaked on nutrient agar media separately. The plates were incubated at $37^{\circ} \mathrm{C}$ for 24 hours. After incubation, colony characteristics were studied. The colony was transformed to slants for further characterization.

\section{Sample-2 $^{\text {nd }}$ (After 7 days)}

After 7 days, sample was collected from upper surface and lower surface of cow dung separately. Inoculum was made from the upper surface on nutrient agar medium, after that sterilized the loop again over the flame, till it became hot red. The plate was turned and streaked over agar surface. Incubation of all the plates was done at $37^{\circ} \mathrm{C}$ for 24 hours. Same procedure was repeated for lower surface sample.

\section{Sample-3 ${ }^{\text {rd }}$ (after 15 days)}

Sample of cow dung from upper surface and lower surface was collected after 15 days for isolation of bacteria. By applying the both pour plate method \& streak plate method.

\section{Streak plate method}

The sample was taken with sterilized inoculating loop and streaked at the medium of the plates. Then the plates were incubated at $37^{\circ} \mathrm{C}$ for 24 hours.

\section{Pour plate method}

In pour plate method the sample was picked from upper surface and lower surface separately by the help of sterilized inoculating loop and transferred in Petri plates separately, after that the media $\left(47^{0} \mathrm{C}\right)$ was poured in the 
plates. The plates were rotated and left for solidification. All plates were incubated in incubator at $37^{\circ} \mathrm{C}$ for 24 hours.

Sample- $4^{\text {th }}$ (after 21 days)

After 21 days sample was collected from both upper and lower surface of cow dung. Both pour plate method and streak plate method were applied for isolation of bacteria from cow dung.

\section{Streak plate method}

The sample was taken by sterilized inoculating loop and inoculum was made on nutrient agar media and line was drawn over agar surface, (streak plate method) for both upper and lower surface sample separately. All the plates were incubated for 24 hours at $37^{\circ} \mathrm{C}$ temperature, and then single colony was isolated and transferred this colony in nutrient agar slant.

\section{Pour plate method}

The sample was taken from upper surface by the help of sterilized inoculating loop and transferred on Petri plates separately and the media (nutrient agar media) was poured, sample was mixed gently and left the plates for solidification.

After solidification, all the plates were incubated at $37^{\circ} \mathrm{C}$ for 24hours and then single colony was transferred on nutrient agar slant, after that same process was repeated for lower surface sample. The bacterial culture was maintained on nutrient agar media.

\section{Sample- $5^{\text {th }}$ (after 31 days)}

After 31 days sample was collected from upper and lower surface. Both method (pour plate \& streak plate method) applied for isolation of bacteria.

\section{Streak plate method}

Sample was taken by sterilized inoculating loop aseptically from upper surface and transferred over the sample by drawing straight line over agar surface. All the plates were incubated at $37^{\circ} \mathrm{C}$ for 24 hours. The same process was repeated for isolation of bacteria from lower surface.

\section{Pour plate method}

The upper surface sample was transferred in the sterilized Petri plates by the help of sterilized inoculating loop, under aseptic condition. The nutrient agar media was poured in Petri-plates and mixed gently and the plate was left for solidification. After solidification all plates were incubated at $37^{0} \mathrm{C}$ for 24 hours. The same process was repeated for lower surface sample.

\section{Characterization and Identification of micro-organisms}

After isolation pure colonies of bacteria were identified and characterized on the basis of morphological analysis such as color, size and shape. These colonies of bacteria were identified by the Gram's staining method.

\section{Effect of Different pH on the growth of bacteria}

Isolated bacteria were grown on media with different $\mathrm{pH}$ values.

\section{Preparation of Different pH media}

Media of different $\mathrm{pH}$ was prepared by addition of different $\mathrm{pH}$ buffer solution named according to $\mathrm{pH}$ as $\mathrm{pH}-2, \mathrm{pH}-4, \mathrm{pH}-6$, $\mathrm{pH}-7 \& \mathrm{pH}-8$. Two plates of each $\mathrm{pH}$ buffer was prepared and the pure culture of isolated bacteria was transferred by the help of sterilize inoculating loop aseptically on each nutrient agar media done by streak plate 
method. Among the streaked plates, one plate from each $\mathrm{pH}$ was incubated at $37^{\circ} \mathrm{C}$ for 24 hours, and second streaked plate of different $\mathrm{pH}$ plates was incubate at room temperature for 24 hours.

\section{Results and Discussion}

In this study, cow dung was collected and left it for $31^{\text {st }}$ days. The sample was taken at different time interval of days- 2, 7, 15, 21, $31^{\text {st }}$ days. Sample was taken from upper and lower surface in a sterilized container. Different bacteria were isolated from cow dung on nutrient agar media from upper and lower surface and identified by Gram's Staining.

Among the isolated bacteria the Bacillus was present in high amount as compared to other bacteria, such as Enterococcus, Diplococcus, Pseudomonas and thread like bacteria.
Enterococcus was dominant on other bacterial growth. These bacteria were characterized on the basis of morphological and biochemical analysis as per Table 2. On the basis of gram's staining, bacteria were differentiated as gram positive and gram negative bacteria shown in Figure 10. Bacillus, Diplococcus, Enterococcus were gram positive bacteria and show purple colour after gram's staining. Pseudomonas show pink colour, rod shape after gram's staining. Isolated bacillus was central endospore forming bacteria.

\section{Effect of different pH level on Bacillus}

From the isolated bacteria by gram staining the bacillus was found in high amount than other bacteria so we check the effect of different $\mathrm{pH}$ level on growth of bacillus. There was no effect of $\mathrm{pH}$ on the growth of bacteria, optimal temperature for growth was $37^{\circ} \mathrm{C}$.

Table.1 Composition of NAM (Nutrient agar media)

\begin{tabular}{|c|c|c|}
\hline S.No & Chemicals & Amount Required \\
\hline $\mathbf{1 .}$ & Peptone & $5.0 \mathrm{gm}$ \\
\hline $\mathbf{2 .}$ & $\mathrm{NaCl}$ & $5.0 \mathrm{gm}$ \\
\hline $\mathbf{3 .}$ & Beef extract & $3.0 \mathrm{gm}$ \\
\hline $\mathbf{4 .}$ & Yeast extract & $3.0 \mathrm{gm}$ \\
\hline $\mathbf{5 .}$ & Agar & $15.0 \mathrm{gm}$ \\
\hline $\mathbf{6 .}$ & Distilled water & $1000 \mathrm{ml}$ \\
\hline
\end{tabular}

Table.2 Growth of bacteria at different surface of cow dung

\begin{tabular}{|c|c|c|c|c|}
\hline S.No. & Sample/Time duration & $\begin{array}{c}\text { Gram's } \\
\text { staining } \\
\text { Purple color }\end{array}$ & $\begin{array}{c}\text { Lower } \\
\text { Surface }\end{array}$ & $\begin{array}{c}\text { Upper } \\
\text { Surface }\end{array}$ \\
\hline 1. & Cow dung sample (after 2nd days) & Bacillus \\
\hline 2. & Cow dung sample (after 7days) & $\begin{array}{c}\text { Purple } \\
\text { Colour }\end{array}$ & Bacillus \\
\hline 3. & Cow dung sample (after 15days) & $\begin{array}{c}\text { Purple \& Pink } \\
\text { colour }\end{array}$ & $\begin{array}{c}\text { Bacillus \& } \\
\text { pseudomonas }\end{array}$ & Diplococcus \\
\hline $\mathbf{4 .}$ & Cow dung sample (after 21st days) & Purple colour & Bacillus & Bacillus \\
\hline $\mathbf{5 .}$ & Cow dung sample (after 31st days) & Purple colour & $\begin{array}{c}\text { Thread like } \\
\text { bacteria }\end{array}$ & Enterococcus \\
\hline
\end{tabular}


Table.3 Growth of different $\mathrm{pH}$ level and temperature

\begin{tabular}{|l|c|c|c|c|c|}
\hline \multirow{2}{*}{ Different Temperature } & \multicolumn{5}{|c|}{ Different pH level } \\
\cline { 2 - 6 } & pH-2 & pH-4 & pH-6 & pH-7 & pH-8 \\
\hline Room Temperature & + & + & ++ & ++ & ++ \\
\hline Incubator temperature $\left(\mathbf{3 7}^{\circ} \mathbf{C}\right)$ & ++ & ++ & ++ & ++ & ++ \\
\hline
\end{tabular}

* + Sign represents moderant growth; ++ Represents good growth

Figure.1 Sample $1^{\text {st }}$ after 2 days

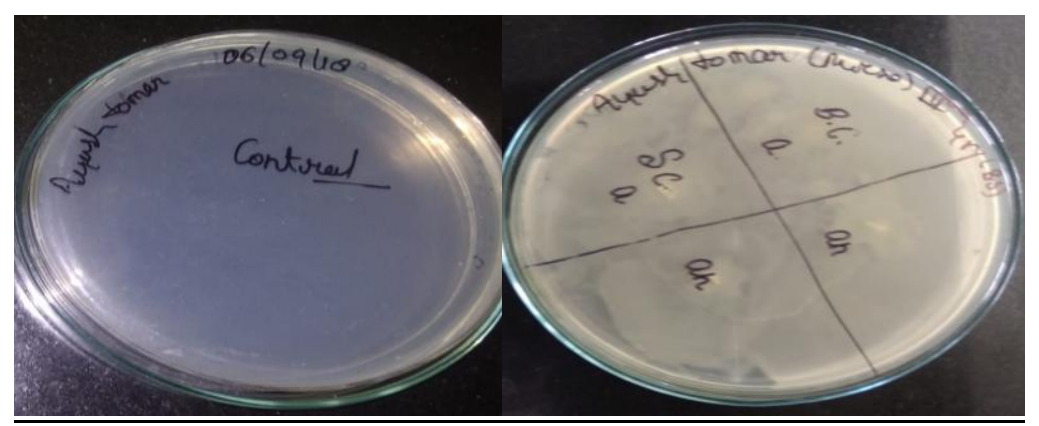

Figure. 2 Sample $2^{\text {nd }}$ after 7 days

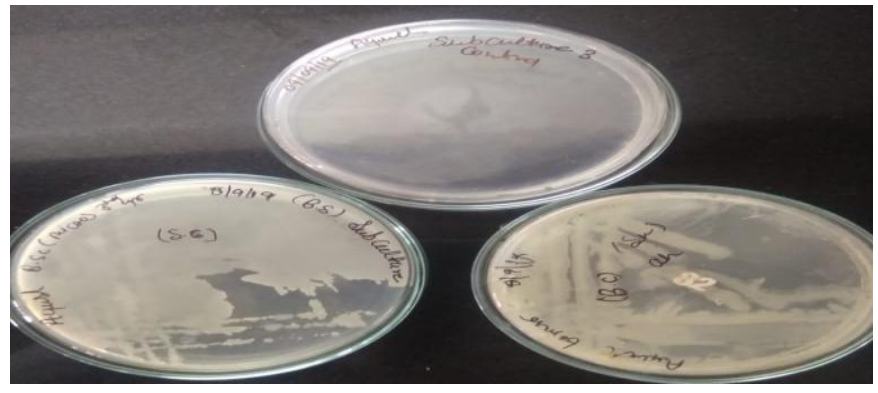

Figure.3 Sample $3^{\text {rd }}$ after 15 days

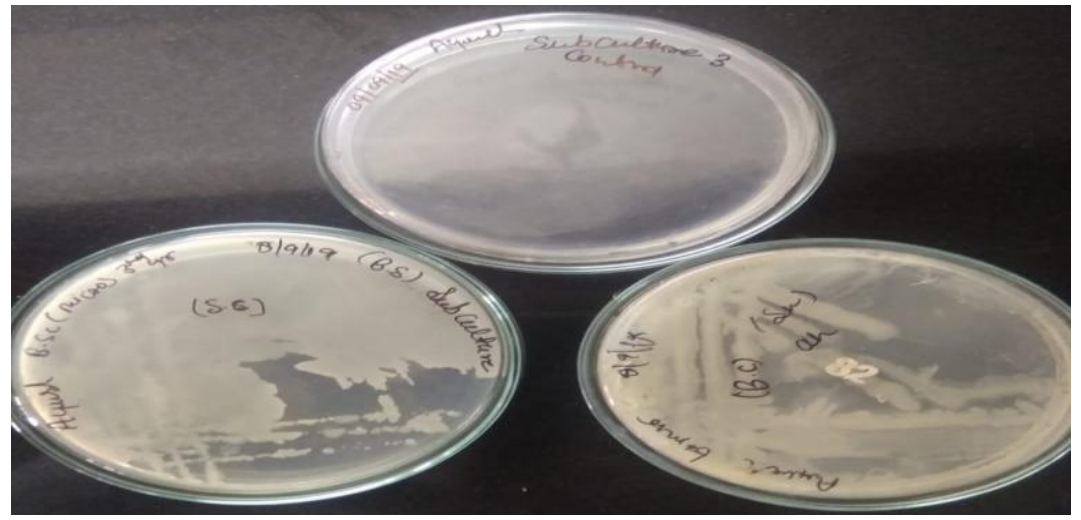


Figure.4 Sample $3^{\text {rd }}$ after 15 days (Pour Plate Method)

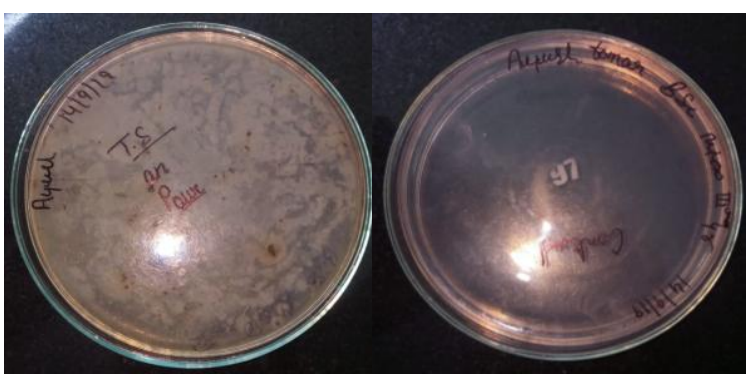

Figure.5 Sample $4^{\text {th }}$ after 21 days (Streak plate method)

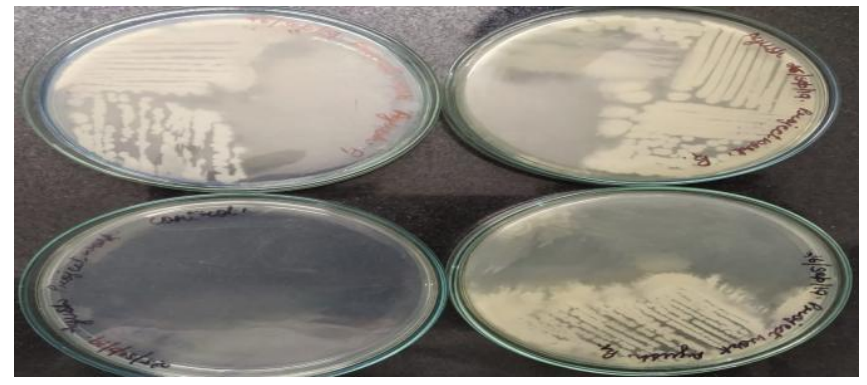

Figure.6 Sample $4^{\text {th }}$ after 21 days (Spread Plate Method)

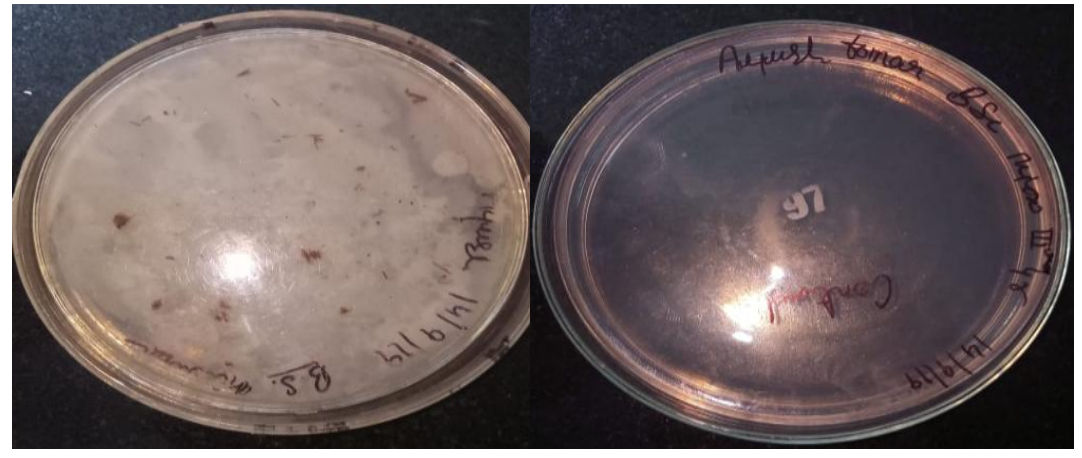

Figure. 7 Sample $5^{\text {th }}$ after 31 days (Streak plate method)

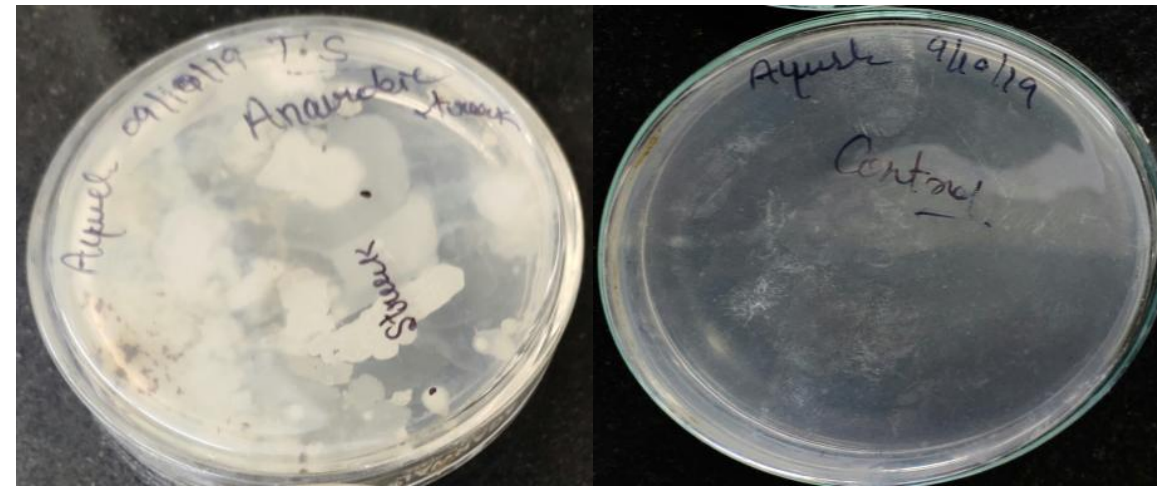


Figure.8 Sample $5^{\text {th }}$ after 31 days (Pour Plate Method)

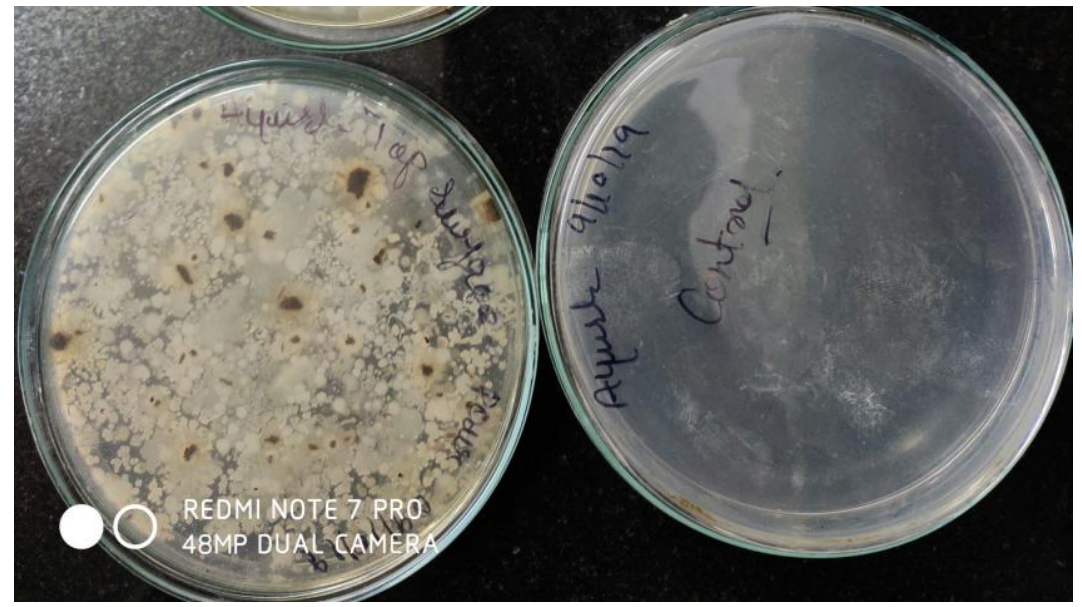

Figure.9 Isolated Pure Culture Plates of Different $\mathrm{pH}$ by Streak Plate Method (A- at Room temperature; B- at Incubator Temperature)

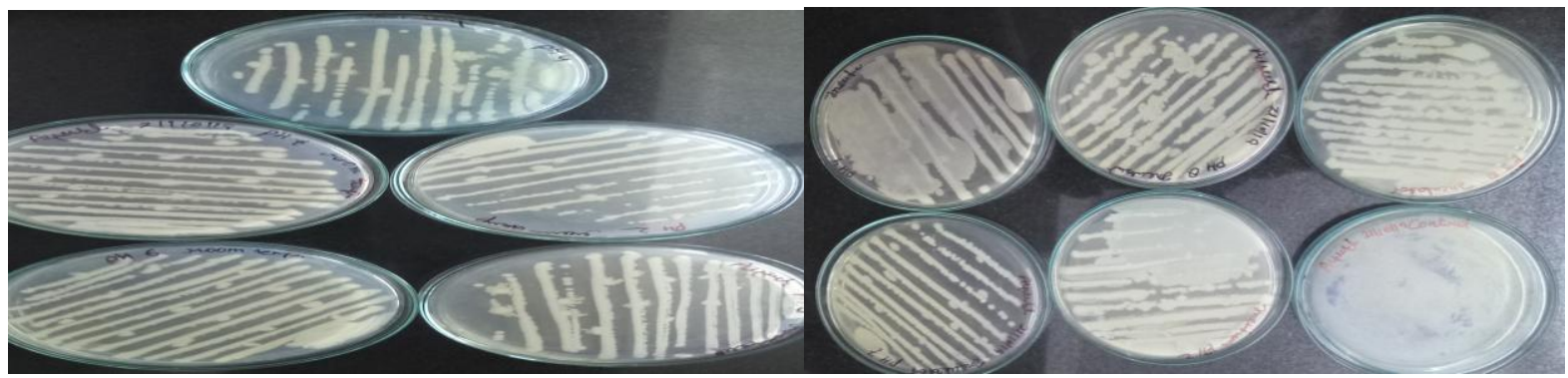

Figure.10 Different types of bacteria were identified such as A: Bacillus; B: Pseudomonas; C: Endospore forming Bacillus; D: Enterococcus; E: Thread like Structure; F: Diplococcus

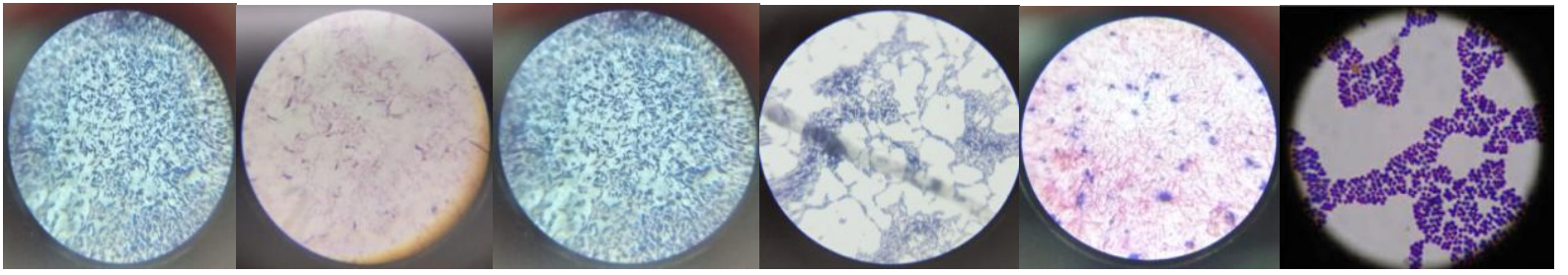

In conclusion, it was found that various species of gram positive bacteria were present in cow dung such as - Bacillus spp., Enterococcus, Diploccocus and gram negative bacteria such as - pseudomonas. Enterococcus was present in dormant condition which affects the growth of other bacteria. According to time, number of Bacillus species was increasing in cow dung and present in motile condition. It is concluded that the micro-flora of cow dung shows the isolated bacteria is endospore forming bacillus. The Enterococcus show dormant nature on nutrient agar media and inhibit the growth of other bacteria. Hence, the Enterococcus cultures work as a bacteriostatic for the growth of other bacteria. 


\section{References}

Abdulkareem, A.S. (2005). Refining biogas produced from biomass: An alternative to cooking gas. Leonardo J. Sci. 7:1-8.

Aneja, K.R. (2003). Experiments on Microbiology, Plant pathology and Biotechnology. New Age International (P) Limited Publishers, New Delhi: 4 edition.

Cavaletti, L., Monciardini, P., Bamonte, R., Schumann, P., Rohde, M., Sosio, M. and Donadio, S. (2006). New lineage of filamentous, spore forming, Gram Positive bacteria from soil. Appl. Environ. Microbiol. 72:4360-4369.

Muhammad, S. and Amusa, N.A. (2003). In vitro inhibition of growth of some seedling blight inducing pathogens by compost inhabiting microbes. Afr.J. Biotechnol, 2:161-164.
Sharma, B. and Singh, M. (2015). Isolation and charactreization of bacteria from cow dung of desi cow breed on different morpho-biochemical parameters in Dehradun. International journal of Advances in Pharmacy, Biology and Chemistry, Vol:4(2).

Singh, A. and Hayashi, K. (1995). Microbial cellulases, protein architechure, molecular properties and biosyhthesis. Advance Applied Microbial, 40:1-4.

Teo, K.C. and Teoh, S.M. (2011). Preliminary biological screening of microbes isolated from cow dung in Kampar. African journal of Biotechnology, Vol: 10(9), pp. 16401645.

Ware Fungsin, D.R., Read, P.L., Mantredi, E.T. (1988). Lactation performance of two large dairy herds fed Lactobacillus acidophilus strain BT 1386. J. Dairy Sci, 71: 219-222.

\section{How to cite this article:}

Ayush Tomar, Shalu Choudhary, Lalit Kumar, Megha Singh, Nisha Dhillon and Sonam Arya. 2020. Screening of Bacteria Present in Cow Dung. Int.J.Curr.Microbiol.App.Sci. 9(02): 584591. doi: https://doi.org/10.20546/ijcmas.2020.902.073 